in ether; the barium, calcium, and lead salts are insoluble in water, acetone, and alcohol, but soluble in ether.

Nearly one-half of the phosphatide fraction is soluble in hot acetone. After purification by saponification, recrystallisation, and distillation, a material resembling paraffin wax was obtained, but the melting-point was indefinite, indicating that it was a mixture. By fractional distillation at $0.1 \mathrm{~mm}$. pressure and crystallisation from benzene-alcohol, the hydrocarbon $\mathrm{C}_{29} \mathrm{H}_{60}$ was obtained in the pure state. The formula was confirmed by X-ray analysis. The higher boiling fractions from the distillation were treated with hydroxylamine; the ketoxime was separated from the hydrocarbon by means of its greater solubility in light petroleum and acetone, and the ketone finally regenerated by boiling in hydrochloric acid alcohol. X-ray analysis indicated that it was either $\mathrm{CH}_{3} \cdot\left(\mathrm{CH}_{2}\right)_{13} \mathrm{CO} \cdot\left(\mathrm{CH}_{2}\right)_{13} \mathrm{CH}_{3}$ or $\mathrm{CH}_{3} \cdot\left(\mathrm{CH}_{2}\right)_{14} \cdot \mathrm{CO} .\left(\mathrm{CH}_{2}\right)_{12} \cdot \mathrm{CH}_{3}$; both were accordingly synthesised, when it was found that the substance was di- $n$-tetradecyl-ketone. Nonocosane and the ketone occur in the ratio of 3 to 1 . Small quantities of other unidentified substances are also present in this fraction of the cytoplasm.

Maclean and her co-workers (Biochem. J., vol. 23, pp. 107 and $634 ; 1929$ ) have also isolated from cab. bage leaves nonacosane and di-n-tetradecyl-ketone; from spinach leaves, however, the hydrocarbon hentriacontane, $\mathrm{C}_{31} \mathrm{H}_{64}$, was obtained.

In conclusion, it may be mentioned that Maclean has isolated from yeast fat a second sterol which she has named 'zymosterol'. The crude sterol was separated, by recrystallisation from alcohol, ether, and acetone, into the less soluble ergosterol, m.p. $158.5^{\circ}$, and a sterol, m.p. $108^{\circ}-109^{\circ}$ (zymosterol) (ibid., vol. 22 , p. $22 ; 1928$ ). The latter is dextrorotatory (in ethereal solution), the former levorotatory (in chloroform). It probably has the same number of ethenoid linkages as ergosterol and a very similar structure; it is precipitated by digitonin, but shows no selective absorption in the ultra-violet. It cannot be converted into vitamin $D$ by irradiation (ibid., p. 980$)$.

\title{
International Congress of Archæology and Anthropology, Portugal, I930.
}

$\mathrm{R}$

EADERS of NATURE will have in mind the recent criticisms of the international standing of the congresses in archæology and anthropology which have been held since the War under the auspices of the Institut International d'Anthropologie of Paris. These were summarised in the leading article in our issue of Mar. 1. In the recently issued announcement of the Congress to be held in Portugal on Sept. 21-30 next, it would now appear that the promoters hope to meet objections which have been raised on the ground that the Congress is not truly international in character by indicating that this congress will be a continuation of the older series of the International Congresses in Anthropology and Prehistoric Archæology, of which the last was held at Geneva in 1912. The invitation is issued jointly by the Conseil permanent du Congrès International d'Anthropologie et d'Archéologie Préhistorique and the Institut International d'Anthropologie. It is announced as the " $\mathrm{xv}^{\mathrm{e}}$ Congrès International d'Anthropologie ot d'Archéologie Préhistorique" and the "ive Session de l'Institut International d'Anthropologie " ; finally, it is pointed out that the meeting coincides with the fiftieth anniversary of the Congress held in Lisbon in 1880 .

While welcoming with all good will this expression of the desire of the members of the Institut that the congress should be regarded as truly international, it must be pointed out that it is not sufficient to call it so, or even to announce that it is a continuation of a former congress which has not met for eighteen years. The only international element in the organisation is the committee in charge of the preparation of the scientific proceedings, which, it is understood, has no executive power and on which Great Britain is not represented. The committees responsible for local arrangements at Coimbra and Oporto naturally are entirely local, but the publications committee is French with two exceptions. The real executive of the Congress, we presume, is constituted as before. The invitation is issued from the Siège Social of the Institut, namely, the Écoled'Anthropologie, and notfrom Lisbon.

Of the "Conseil permanent" of the older Congress, M. Marcellin Boule is a member of the Comité d'Honneur, and M. Pittard represents Switzerland on the committee in charge of the preparation of the scientific proceedings.

The Congress will be divided into sections, of which the first will deal with questions of morphological anthropology and functional ethnology, among the points specifically mentioned in this division being the methods of anthropology and especially the interpretation of statistics, the human brain from the racial point of view, endocrinology and human morphology, and the relation between the yellow races of Africa (Bushman) and the yellow races of Asia.

The second section will deal with human palæontology and prehistoric archæology, in which the question of the Kitchen midden people of Portugal, Armorica, and Denmark will be discussed. Another subject will be the distribution of cereals in neolithic times as well as the origin of domestic animals, particularly the dog.

The third section will deal with heredity, eugenics and cognate subjects, including criminology and psycho-sociology.

The fourth section is of a comprehensive character, covering ethnography, folklore, linguistics, religions, and human geography. One topic of discussion specifically mentioned is the geographical and ethnic origin of the Aurignacians. Primitive survivals among civilised peoples should give rise to lively discussion.

The session will be formally declared open by His Excellency the Minister of Public Instruction, Prof. Gustavo C. Ramos, on Sept. 21, at Coimbra, and a dinner will be given by the Rector of the University on the same day. On the following days, after the work of the sections has closed, conversaziones or illustrated lectures will be given in the evening. On Sept. 26 an archæological excursion will be made to Figueira da Foz on the way to Oporto. On Sept. 26 the Congress reopens at Oporto, on the evening of which day there will be a folk-lore fête at the Palais du Cristal, and on Sept. 27 the Congress will be formally declared closed, a banquet being held after. wards. On Sunday a motor expedition of archæological interest will be made to Guimaraes and Citania de Briteiros. The Congress will arrive at Lisbon on Monday, Sept. 29, at midday. A formal reception will be held by His Excellency General Carmona, President of the Portuguese Republic, and the following and final day will be spent in visits to museums and other places of interest.

Intimation of intention of attending the Congress and subscriptions should be addressed to le Trésorier de l'Institut International, 15 rue de l'École de Médecine, Paris $\left(6^{\mathrm{e}}\right)$. 